\title{
The Value of a Panel of Autoantibodies for Predicting the Activity of Lupus Nephritis at Time of Renal Biopsy
}

\author{
Gabriella Moroni, ${ }^{1}$ Silvana Quaglini, ${ }^{2}$ Antonella Radice, ${ }^{3,4}$ Barbara Trezzi, ${ }^{4}$ \\ Francesca Raffiotta, ${ }^{1}$ Piergiorgio Messa, ${ }^{1}$ and Renato Alberto Sinico ${ }^{4}$ \\ ${ }^{1}$ Division of Nephrology, Fondazione Ospedale Maggiore, Mangiagalli, Regina Elena, 20122 Milano, Italy \\ ${ }^{2}$ Department of Informatics, Università degli Studi di Pavia, 27100 Pavia, Italy \\ ${ }^{3}$ Institute of Microbiology, Azienda Ospedaliera, Ospedale San Carlo Borromeo, 20153 Milano, Italy \\ ${ }^{4}$ Renal Unit and Clinical Immunology Unit, Azienda Ospedaliera, Ospedale San Carlo Borromeo, 20153 Milano, Italy
}

Correspondence should be addressed to Renato Alberto Sinico; renatoalberto.sinico@fastwebnet.it

Received 3 December 2014; Accepted 16 February 2015

Academic Editor: Douglas C. Hooper

Copyright (C) 2015 Gabriella Moroni et al. This is an open access article distributed under the Creative Commons Attribution License, which permits unrestricted use, distribution, and reproduction in any medium, provided the original work is properly cited.

\begin{abstract}
Few studies have correlated serum biomarkers with renal histology, the gold standard for renal activity, in lupus nephritis (LN). We tested a panel of autoantibodies and complement at the time of kidney biopsy and after treatment. Anti-dsDNA, anti-nucleosome, anti-ribosome $\mathrm{P}$, and anti-Clq antibodies and $\mathrm{C} 3 / \mathrm{C} 4$ were measured in 107 patients with $\mathrm{LN}$ at the time of renal biopsy and after 6-12 months and were correlated with clinical/histological parameters. At multivariate analysis, high titers of anti-Clq antibodies or of anti-dsDNA antibodies ( $P=0.005, \mathrm{OR}=8.67, \mathrm{CI}$ : $2.03-37.3)$ were the independent predictors that discriminate proliferative from nonproliferative LN. All the immunological parameters, except anti-ribosome, showed a significant correlation with activity index but not with chronicity index. Only anti-Clq showed a significant correlation with the amount of proteinuria $(R=0.2$, $P=0.03$ ). None of the immunological parameters were predictive of remission at 6 and 12 months. We found that anti-Clq alone or in combination with anti-dsDNA emerged as the most reliable test in differentiating proliferative and nonproliferative LN. Anti$\mathrm{Clq}$ was the only test correlated with the clinical presentation of LN. After treatment, the titre of the autoantibodies was significantly reduced, but none was predictive of remission.
\end{abstract}

\section{Introduction}

Lupus nephritis (LN) is one of the most frequent manifestations of Systemic Lupus Erythematosus (SLE) and represents a major determinant of disease morbidity and mortality [1]. Its clinical course is often characterized by flares of activity alternated with periods of quiescence, generally induced by therapy [2]. The identification of noninvasive biomarkers may help to predict the renal involvement at diagnosis and monitor relapses of LN during the follow-up. Many studies have tested the value of a number of autoantibodies for predicting or confirming the diagnosis of renal flares with contrasting results. Some [3-5] but not all studies [6] have demonstrated that anti-dsDNA antibodies (anti-dsDNA) and complement fractions may be useful in assessing the disease and the renal activity. One paper [7] and a recent review [8] concluded that anti-nucleosome antibodies have high prevalence in severe
LN but are of limited help in differentiating active from inactive LN. A number of cross sectional studies found that antiClq antibodies (antiClq) have a significant association with renal involvement [9-15]. In our previous paper on a large cohort of SLE patients evaluated prospectively for 6 years, we demonstrated that renal exacerbations seem to be quite improbable in the presence of normal values of C3, C4, anti-dsDNA, anti-Clq, and that anti-Clq was slightly better than the other tests to confirm the clinical activity of LN [16].

Noteworthy, in the vast majority of studies the diagnosis of LN flares relies on variable clinical definitions based on activity of urine sediment, amount of proteinuria, and deterioration of renal function, whilst the "gold standard" for the diagnosis of renal activity is represented by renal biopsy. In this prospective study, serum samples at renal biopsy and after the induction therapy of $107 \mathrm{LN}$ patients were tested for a panel of autoantibodies (including anti-dsDNA, anti-Clq, 
anti-nucleosome, anti-ribosome antibodies, and C3 and C4 complement fractions) to investigate their association with the clinical and histological data.

\section{Patients and Methods}

One hundred and seven patients with SLE, diagnosed according to the American College of Rheumatology criteria [17] (94 females, 13 males) at admission in two Italian Renal Units (Fondazione Ospedale Maggiore and Azienda Ospedaliera Ospedale San Carlo Borromeo, Milano) to undergo renal biopsy for assessment of LN, entered the study. The renal biopsies were classified following the ISN/RNP classification [18]. Activity and chronicity indices were calculated according to Austin et al. [19].

Sera at renal biopsy were tested for a panel of auto antibodies including anti-dsDNA and anti-Clq, antinucleosome, and anti-ribosome antibodies as well as $\mathrm{C} 3$ and C4 complement fractions.

The study does not need an ethical approval. We have obtained an informed consent to participate in the study from all the patients involved.

2.1. Objectives. The aim of this study was to assess the performance of these tests in predicting:

(a) the histological classes of lupus nephritis,

(b) the activity and chronicity index at renal biopsy,

(c) the clinical feature of LN at renal biopsy,

(d) the response of lupus nephritis at 3, 6, and 12 months after the beginning of the induction therapy.

2.2. Laboratory Investigations. Anti-dsDNA antibodies were measured by a commercial quantitative ELISA (Varelisa antidsDNA Antibodies, Phadia GmbH, Freiburg, Germany) and C3 and C4 plasma levels by nephelometry (Nephelometer Analyser II, Behring, Marburg GmbH, Germany).

Anti-Clq antibodies were detected using a home-made ELISA as described by Sinico et al. [11].

Anti-nucleosome antibodies were measured by ELISA according to manufacturer instructions using Quanta Lite Chromatin assay (INOVA diagnostics, Inc., San Diego, CA, USA) [20].

Anti-ribosome P antibodies were measured by ELISA according to manufacturer instructions using Quanta Lite Ribosomal P assay (INOVA diagnostics, Inc., San Diego, CA, USA).

2.3. Definition of Activity. At each clinical examination the activity of LN was classified as follows [2]:

$0=$ complete renal remission: normal renal function for at least 6 months, proteinuria $<0.5 \mathrm{~g} / 24 \mathrm{~h}$, and urinary red blood cells $<5 / \mathrm{hpf}$;

1 = partial renal remission: for nephritic flare: improvement of at least $30 \%$ of serum creatinine but persistence of active urinary sediment; for proteinuric flares improvement of $50 \%$ of proteinuria;
$2=$ nephritic flare: increase of $30 \%$ of serum creatinine over the basal value and active urinary sediment (>10 red blood cells/hpf, cellular casts) with or without an increase in proteinuria;

$3=$ proteinuric flare: increase of proteinuria of at least $2 \mathrm{~g} /$ day in patients with non nephrotic syndrome or the doubling of nephrotic proteinuria with stable renal function;

4 = persistent renal activity: the lack of achievement of remission after induction therapy.

\section{Statistical Analysis}

Mean and standard deviation, together with median and interquartile (IQ) range $\left(25^{\circ}-75^{\circ}\right.$ percentile) were used as descriptive statistics. For continuous variables, the nonparametric Wilcoxon test was used for assessing any difference between the two groups of patients, while the chi-square test was used for dichotomized variables. The Spearman correlation was used to analyse correlation.

Multivariate logistic regression analysis has been used to find predictors of histological classes of lupus nephritis and for the predictors of complete renal response after the beginning of induction therapy. Odds ratios (OR) and their $95 \%$ confidence interval (CI) for the covariates were derived as the antilogarithm of the regression coefficients. Multivariate linear regression analysis was used to predict the activity index at renal biopsy.

The statistical package S-Plus (MathSoft Inc.) was used for all the analyses and plots.

\section{Results}

The characteristics of the patients at renal biopsy are reported in Table 1. The 107 patients received 111 renal biopsies (4 patients, 2 biopsies). The mean age at diagnosis of SLE was $35.3 \pm 14.2$ years, (median 34) and that at renal biopsy was $36.4 \pm 13.9$ years (median 36 ). The mean time between the diagnosis of SLE and that of renal involvement was $5.1 \pm 6.5$ years, (median 3 years). In 45 patients, renal involvement was present at diagnosis of SLE.

Considering that a preliminary analysis demonstrated no significant differences in the mean values of C3, C4, anti-dsDNA, anti-Clq, anti-nucleosome, and anti-ribosome antibodies between class II and class $\mathrm{V}$ and between class III and Class IV LN (data not shown), the subsequent analysis was performed comparing Class II plus class V (nonproliferative forms; 26 patients) versus class III plus class IV (proliferative forms; 85 patients).

4.1. Prevalence of Autoantibodies and Histo Pathological Associations. At renal biopsy, high titers of anti-dsDNA were present in $77.5 \%$ of cases, high titers of anti-Clq in $70.5 \%$ of cases, high titers of anti-nucleosome antibodies in $80.3 \%$ of cases, and high titers of anti- ribosome antibodies in $14 \%$ of cases; C3 were low in $82 \%$ of cases and C4 in $74 \%$ of cases. Table 2 reports the comparison at time of renal biopsy of 
TABLE 1: Clinical and histological characteristics at renal biopsy of the 107 lupus nephritis patients enrolled in the study who received 111 renal biopsies.

\begin{tabular}{|c|c|}
\hline Males/females & $13 / 94$ \\
\hline $\begin{array}{l}\text { Age at diagnosis of renal biopsy } \\
(\mathrm{M} \pm \mathrm{SD})\end{array}$ & $36.4 \pm 13.9$ \\
\hline Duration of SLE years $(M \pm S D)$ & $5.1 \pm 6.5$ \\
\hline $\begin{array}{l}\text { Serum creatinine } \mathrm{mg} / \mathrm{dL}(\mathrm{M} \pm \\
\text { SD) }\end{array}$ & $1.07 \pm 0.76$ \\
\hline $\begin{array}{l}\text { Number of patients with serum } \\
\text { creatinine }>1.2 \mathrm{mg} / \mathrm{dL}\end{array}$ & $31(28 \%)$ \\
\hline Proteinuria g/24h $(\mathrm{M} \pm \mathrm{SD})$ & $3.4 \pm 2.85$ \\
\hline $\begin{array}{l}\text { Number of patients with } \\
\text { nephrotic syndrome }\end{array}$ & $44(39.6 \%)$ \\
\hline Hemoglobin g/dL & $11.53 \pm 1.9$ \\
\hline $\begin{array}{l}\text { Class II (number of } \\
\text { patients)/activity } \\
\text { index/chronicity index }\end{array}$ & $8(7.2 \%) / 1.6 \pm 3.2 / 0.4 \pm 0.9$ \\
\hline $\begin{array}{l}\text { Class III (number of } \\
\text { patients)/activity } \\
\text { index/chronicity index }\end{array}$ & $35(31.5 \%) / 5.3 \pm 2.5 / 1.7 \pm 1.74$ \\
\hline $\begin{array}{l}\text { Class IV (number of } \\
\text { patients)/activity } \\
\text { index/chronicity index }{ }^{* *}\end{array}$ & $50(45 \%) / 9.0 \pm 3.2 / 2.1 \pm 1.7$ \\
\hline $\begin{array}{l}\text { Class V (number of } \\
\text { patients)/activity } \\
\text { index/chronicity index }\end{array}$ & $18(16.2 \%) / 1.1 \pm 2.1 / 0.7 \pm 1.2$ \\
\hline $\begin{array}{l}\text { Methylprednisolone pulses } \\
0.5-1 \mathrm{~g} / \text { day for } 3 \text { days }{ }^{* * *}\end{array}$ & $80(72 \%)$ \\
\hline $\begin{array}{l}\text { Oral prednisone } 1 \mathrm{mg} / \mathrm{kg} / \text { day for } \\
1 \text { month }\end{array}$ & $31(28 \%)$ \\
\hline $\begin{array}{l}\text { Oral cyclophosphamide } \\
1-2 \mathrm{mg} / \mathrm{kg} / \text { day for } 2-3 \mathrm{months}\end{array}$ & $36(32 \%)$ \\
\hline $\begin{array}{l}6 \text { fortnightly cyclophosphamide } \\
\text { pulses of of } 0.5 \mathrm{~g}^{\S \S}\end{array}$ & $11(10 \%)$ \\
\hline $\begin{array}{l}6 \text { monthly cyclophosphamide } \\
\text { pulses of } 1 \mathrm{~g} / \mathrm{m}^{2 \S s \S}\end{array}$ & $18(16 \%)$ \\
\hline Mycophenolate mofetil $2 \mathrm{~g} /$ day $^{\$}$ & $20(18 \%)$ \\
\hline $\begin{array}{l}\text { Maintenance therapy: } \\
\text { mycophenolate } \\
\text { mofetil/azathioprine }\end{array}$ & $30 / 21$ \\
\hline
\end{tabular}

$\mathrm{M}$, mean; SD, standard deviation. ${ }^{*}$ including 15 patients with class III $+\mathrm{V}$; ** including 15 patients with class IV $+\mathrm{V} ;{ }^{* * *}$ (1 patient of class II, 27 of class III, 45 of class IV, and 7 of class V); ${ }^{\$}(14$ patients of class III and 22 of class IV); ${ }^{\$ \$}$ ( 3 patients of class III, 6 of class IV, and 2 of class V); ${ }^{\$ \$ \$}(2$ patients of class II, 5 of class III, 10 of class IV, and 1 of class V), ${ }^{\$}$ (2 patients of class II, 5 of class III, 8 of class IV, and 5 of class V).

clinical data and of the panel of autoantibodies between proliferative forms (class III plus class IV) and nonproliferative forms (class II plus class V) of LN. At univariate analysis, among the clinical parameters, proteinuria $(P=0.02)$ and hemoglobin $(P=0.0008)$ and among the immunological tests, C3 $(P=0.02)$ and C4 $(P=0.02)$ complement fractions, anti-DNA $(P=0.001)$, anti-Clq $(P=0.0005)$, and high titers of anti-Clq antibodies or of anti-dsDNA antibodies $(P=$ $0.0000)$ and anti-nucleosome antibodies $(P=0.04)$ were able to differentiate proliferative from nonproliferative forms of
LN. At multivariate analysis, hemoglobin $(P=0.008, \mathrm{OR}=$ 0.68 , CI: $0.52-0.9)$ and anti-Clq antibodies $(P=0.03$, OR $=$ 1.004, CI: $1.0003-1.007)$ were the independent predictors to discriminate between proliferative versus nonproliferative lupus nephritis. Excluding clinical parameters, at multivariate analysis, logarithm of erythrocyte sedimentation rate (ESR) $(P=0.03, \mathrm{OR}=1.9, \mathrm{CI}: 1.08-3.42)$ and high titers of anti-Clq antibodies or of anti-dsDNA antibodies $(P=0.005$, OR $=$ 8.67, CI: 2.03-37.3) are the independent predictors which are able to discriminate proliferative from nonproliferative lupus nephritis. Among patients with proliferative forms of lupus nephritis, $95 \%$ have high titers of anti Clq or of anti-dsDNA (66.2\% have high titers of both anti-Clq and of anti-dsDNA) while $5 \%$ have the results of both tests in a normal range. Among patients with nonproliferative forms, $64 \%$ have high titers of anti Clq or of anti DNA while $36 \%$ have the results of both tests in a normal range $(P=0.000)$.

The correlations among the basal clinical and the immunological data and the activity and the chronicty index at renal biopsy are reported in Table 3. All the clinical and immunological parameters evaluated with the exception for $\mathrm{C}$ reactive protein (CRP) and anti-ribosome antibodies showed a significant correlation with activity index. At multivariate analysis proteinuria $(P=0.0013)$, low $\mathrm{C} 4$ $(P=0.0010)$, and high ESR $(P=0,037)$ were the independent predictors of the activity index. Excluding the clinical variables, low C4 $(P=0.0004)$ and high ESR $(P=$ $0,0025)$ were the independent predictors of activity index.

In contrast, serum creatinine was the only parameter among those evaluated that showed a direct correlation with the chronicity index $(R: 0.4, P=0.0000)$.

\subsection{Correlations between Autoantibodies and Clinical Param-} eters. No correlation was found at time of renal biopsy between serum creatinine and the panel of autoantibodies, $\mathrm{C} 3$ and C4 complement fractions, and ESR and CRP. Among these tests, anti-Clq only showed a significant direct correlation with the amount of proteinuria $(R=0.2, P=$ $0.03)$. In addition, patients with high titers of anti-Clq or of anti-dsDNA had significant higher proteinuria (median $2.7 \mathrm{~g} /$ day, IQ 1.6-4.6) than those with both tests in normal range (1.8 g/day, IQ 1.0-2.2, $P=0.05)$. Anti-Clq, anti-dsDNA, and ESR were inversely correlated with hemoglobin $(R-0.22$, $P=0.02, R-0,24, P=0.01, R-0.32, P=0.002$, resp. $)$, while $\mathrm{C} 3$ and $\mathrm{C} 4$ were correlated with hemoglobin $(R 0.36, P=0.0002$ and $R 0.25, P=0.01$ ).

4.3. Clinical and Immunological Outcome after the Beginning of Induction Therapy. After renal biopsy and the beginning of induction therapy, 104 patients had a second evaluation between 3 and 12 months. Table 4 reported the results of clinical and immunological tests in patients reevaluated at 3 months, at 6 months, and at 12 months. At 3 months, serum creatinine was unchanged and proteinuria did not show a significant improvement, while ESR, C3, anti-DNA, anti-Clq, and anti-nucleosome antibodies showed a significant improvement in the median values. At 6 and at 12 months, proteinuria significantly improved together with all 
TABLE 2: Comparison of clinical and immunological features between nonproliferative forms (class II + class V) and proliferative forms (class III + class IV) lupus nephritis.

\begin{tabular}{|c|c|c|c|}
\hline & $\begin{array}{c}\text { Non proliferative LN } \\
26 \text { patients }\end{array}$ & $\begin{array}{c}\text { Proliferative LN } \\
85 \text { pateints }\end{array}$ & $P$ \\
\hline Serum creatinine $\mathrm{mg} / \mathrm{dL}$ & $0.8(0.67-0.96)$ & $0.9(0.74-1.15)$ & Ns \\
\hline Proteinuria g/day & $1.94(1-2.74)$ & $2.8(1.6-4.7)$ & 0.02 \\
\hline Hemoglobin g/dL & $12.9(11.3-14)$ & $11.2(9.8-12.3)$ & 0.0008 \\
\hline Activity index & $1(0-3)$ & $7(5-9)$ & 0.0000 \\
\hline Chronicity index & $1(0-2)$ & $2(1-3)$ & 0.02 \\
\hline $\begin{array}{l}\text { Erythrocyte sedimentation rate } \\
\mathrm{mm}\end{array}$ & $21(11-46.5)$ & $37.5(20.7-71.5)$ & 0.07 \\
\hline $\mathrm{C}$ reactive protein $\mathrm{mg} / \mathrm{dL}$ & $0.39(0.08-0.89)$ & $0.3(0.11-0.6)$ & Ns \\
\hline $\mathrm{C} 3 \mathrm{mg} / \mathrm{dL}$ & $72(60-94)$ & $62(46.7-80.5)$ & 0.02 \\
\hline $\mathrm{C} 3<90 \mathrm{mg} / \mathrm{dL}$ & $65 \%$ & $87.3 \%$ & 0.08 \\
\hline $\mathrm{C} 4 \mathrm{mg} / \mathrm{dL}$ & $13(9-19)$ & $8.5(5-14)$ & 0.02 \\
\hline $\mathrm{C} 4<15 \mathrm{mg} / \mathrm{dL}$ & $57.6 \%$ & $78.8 \%$ & 0.01 \\
\hline Anti-DNA antibodies $\mathrm{U} / \mathrm{mL}$ & $67(18-135)$ & $183(85-400)$ & 0.001 \\
\hline Anti-DNA antibodies $\mathrm{U} / \mathrm{mL}>50$ & $50 \%$ & $86 \%$ & 0.001 \\
\hline Anti-Clq antibodies AU & $41(22-123)$ & $216(63-320)$ & 0.0005 \\
\hline Anti-Clq antibodies $\mathrm{AU}>55$ & $44 \%$ & $79 \%$ & 0.003 \\
\hline Anti-nucleosome $\mathrm{Ab} \mathrm{U}$ & $51(18.5-97)$ & $95(44-118)$ & 0.04 \\
\hline $\begin{array}{l}\text { Anti-nucleosome antibodies Ab } \\
U>20\end{array}$ & $68 \%$ & $84 \%$ & 0.02 \\
\hline $\begin{array}{l}\text { Anti-DNA >50 U/mL or anti-Clq } \\
>55 \mathrm{AU}\end{array}$ & $9(36 \%)$ & $80(95 \%)$ & 0.000 \\
\hline Anti-ribosome antibodies & $3(2-5.5)$ & $2(2-6)$ & Ns \\
\hline Anti-ribosome antibodies $>20$ & $16 \%$ & $13 \%$ & Ns \\
\hline Lupus anti-coagulant positivity & $22.7 \%$ & $15,4 \%$ & Ns \\
\hline Antiphospholipid antibodies & $32 \%$ & $25 \%$ & Ns \\
\hline
\end{tabular}

The data are reported as Median and interquartile ranges.

immunological tests with the exception of ESR at 6 months and anti-ribosome antibodies at 12 months.

Altogether, during the observation period, 39 patients (37.5\%) achieved and $65(62.5 \%)$ did not achieve complete renal remission (46 were in partial remission, 13 had persistent renal activity, and 6 had persistent nephrotic syndrome). Clinical and immunological tests at the time of renal biopsy have been tested as predictors of complete renal remission (Table 5). At univariate analysis, none of the immunological tests were predictive of complete remission. At multivariate analysis, proteinuria $(P=0.015$, OR: $0.76 \mathrm{CI} 0.62-0.95)$ and the duration of therapy ( $P=0.03$ OR: 1.19 CI 1.017-1.39) were the independent predictors of complete renal remission.

\section{Discussion}

In this study, we have investigated the prevalence and the value of a panel of autoantibodies (anti-dsDNA, anti-C1q, anti-nucleosome, and anti-ribosome antibodies) as well as C3 and $\mathrm{C} 4$ complement fractions in predicting the activity of LN at the time of renal biopsy. The most important difference of our study compared to many previous studies is the timing of blood sampling in relation to renal activity. As a matter of fact, in the majority of the studies evaluating the predictive values of autoantibodies $[11,15,21-23]$, the renal activity of LN at the time of blood sampling was judged by clinical parameters but not confirmed by renal biopsy. To the best of our knowledge, only a few studies have evaluated the association of some autoantibodies with activity of LN at the time of renal biopsy [24-27]. Trendelenburg et al. [24] reported that all but one out of 36 patients with proliferative lupus were positive for anti-Clq at the time of renal biopsy compared with $35 \%$ of patients with inactive LN. In 136 Chinese patients [25], anti-Clq and anti-dsDNA were more closely correlated with histological activity of LN at the time of renal biopsy than anti-extractable nuclear antigen antibodies, anti-C protein antibodies, anti cardiolipin, and anti Beta2 glycoprotein antibodies. The combination of anti-Clq and anti-dsDNA indicates higher renal disease activity and predicts poor long term renal outcome. Another paper [26] investigated the clinical and pathological association of anti-Clq in LN and found a higher prevalence of the autoantibody in class IV than in the other histological classes. Among the clinical variables low haemoglobin was associated with anti-Clq positivity. 
TABLE 3: Correlations of activity and chronicity index with clinical and immunological tests.

\begin{tabular}{|c|c|c|c|c|}
\hline & $\begin{array}{c}\text { Activity } \\
\text { index } \\
R\end{array}$ & $P$ & $\begin{array}{l}\text { Chronicity } \\
\text { index } \\
R\end{array}$ & $P$ \\
\hline $\begin{array}{l}\text { Serum creatinine } \\
\mathrm{mg} / \mathrm{dL}\end{array}$ & 0.23 & 0.017 & 0.4 & 0.0000 \\
\hline Proteinuria g/day & 0.3 & 0.0014 & 0.17 & 0.08 \\
\hline $\begin{array}{l}\text { Erythrocyte } \\
\text { sedimentation rate } \\
\mathrm{mm}\end{array}$ & 0.24 & 0.02 & Ns & Ns \\
\hline $\begin{array}{l}\mathrm{C} \text { reactive protein } \\
\mathrm{mg} / \mathrm{dL}\end{array}$ & Ns & Ns & Ns & Ns \\
\hline $\mathrm{C} 3 \mathrm{mg} / \mathrm{dL}$ & -0.34 & 0.0003 & Ns & Ns \\
\hline $\mathrm{C} 4 \mathrm{mg} / \mathrm{dL}$ & -0.28 & 0.004 & Ns & Ns \\
\hline $\begin{array}{l}\text { Anti-DNA antibodies } \\
\mathrm{U} / \mathrm{mL}\end{array}$ & 0.31 & 0.001 & Ns & Ns \\
\hline $\begin{array}{l}\text { Anti-Clq antibodies } \\
\text { AU }\end{array}$ & 0.24 & 0.01 & Ns & Ns \\
\hline $\begin{array}{l}\text { Anti-nucleosome } \\
\text { antibodies Ab U }\end{array}$ & 0.29 & 0.041 & Ns & Ns \\
\hline $\begin{array}{l}\text { Anti-Ribosome } \\
\text { antibodies }\end{array}$ & Ns & Ns & Ns & Ns \\
\hline Lupus anticoagulant & Ns & Ns & Ns & Ns \\
\hline $\begin{array}{l}\text { Antiphospholipid } \\
\text { antibodies }\end{array}$ & Ns & Ns & Ns & Ns \\
\hline
\end{tabular}

In this paper, we have shown that there was a significant difference in the autoantibodies profile between proliferative forms (class III plus IV) and the other forms of LN (class $\mathrm{V}$ and class 11). All the autoantibodies evaluated, with the exception of anti-ribosome antibodies, had significant higher prevalence and higher titres in proliferative than in nonproliferative forms of LN. C3 and C4 complement fractions too were significantly lower in proliferative than in nonproliferative LN. At multivariate analysis, considering clinical and immunological tests, only low haemoglobin and high anti-Clq were the independent predictors of proliferative LN. Excluding the clinical variables, high ESR and positive anti-Clq or anti-dsDNA were able to discriminate between proliferative and nonproliferative LN. Ninety-five percent of patients with proliferative LN had high titers of anti Clq or of anti-dsDNA (66.2\% had high titers of both tests) while 4 patients only had the results of both tests in normal range. The increasing power of the combination of anti-Clq or antidsDNA positivity in predicting the activity of LN has been reported by other studies $[25,28]$.

This higher predictive value of anti Clq for proliferative LN confirmed our findings in a previous study in which we demonstrated that $80 \%$ of flares that developed in patients with proliferative forms were associated with high titres of anti-Clq in comparison to only $54 \%$ of those that occurred in the nonproliferative forms [16]. Instead, other cohort studies did not show differences in the prevalence of antiClq between proliferative and nonproliferative lupus nephritis [28-30].
This discrepancy could be due to the fact that in these studies the diagnosis of renal activity was done on clinical grounds and not confirmed by renal biopsy. Again, anti-Clq, alone or associated with anti-dsDNA, was the only test among the immunological parameters that significantly correlated with the amount of proteinuria. None of the immunological tests correlated with serum creatinine but the majority of our patients had normal renal function, and many tests correlated with hemoglobin, a manifestation not specific for LN but an expression of the general activity of SLE. Low C4 and high ESR were the independent predictors of a high activity index at multivariate analysis while none of the tests of the panel correlated with chronicity index.

In contrast to what was reported by Yang et al. [25], in our cohort, none of the immunological tests at the time of renal biopsy was predictive of the renal response, at least in the short term. However, we have shown that, three months after the start of the induction therapy and prior to the improvement of proteinuria, a significant reduction of the mean value of anti-Clq, anti-dsDNA, and anti-nucleosome antibody occurred. The progressive and significant drop in autoantibodies titres continued at 6 and at 12 months together with a clinical improvement as reported in other studies [24, 26, 31].

Anti-Clq antibodies can be detected by different methods (reviewed in $[32,33]$ ). In the early 1980 s, a solid-phase assay using purified $\mathrm{Clq}$, immobilized on plastic assay plates, was used for the detection of circulating immune complexes in SLE patients. To differentiate between immune complexes and anti-Clq antibodies, high-salt concentrations (0.5-1.0 M sodium chloride) were used. Using this method, the binding of the globular heads of $\mathrm{Clq}$ to immune complexes is prevented, whereas anti-Clq antibodies can still interact with the coated Clq. Subsequently, to eliminate the need to use high-ionic strength buffer, assays have been developed that utilize only the $\mathrm{Clq}$ collagen-like region. The use of the purified collagen-like region may potentially be more reliable. However, additional exposed epitopes, by cleaving of the $\mathrm{Clq}$ molecule, might interfere with the results obtained with this assay. More recently, peptides derived from Clq that have the properties to detect a major linear epitope in a high percentage of the patients in the absence of highionic strength buffer has been proposed [33]. Unfortunately, systematic studies comparing anti-Clq antibody detected by different assays are not available and different studies have used different methods. In our study, we have used the "classic" assay which has been used in the majority of published clinical studies because it is more readily available.

\section{Conclusions}

We found a significantly different autoantibodies profile between proliferative and nonproliferative forms of $\mathrm{LN}$ at the time of renal biopsy. Among the panel of autoantibodies evaluated in this study, anti-Clq alone or in combination with anti-dsDNA emerged as the most reliable in differentiating proliferative and nonproliferative $\mathrm{LN}$ and anti-Clq is the 
TABLE 4: Outcome of clinical and immunological parameters at 3, 6, and 12 months after the beginning of induction therapy.

\begin{tabular}{|c|c|c|c|c|c|c|c|c|c|}
\hline & $\begin{array}{l}\text { Basal } \\
16 \text { pts }\end{array}$ & At 3 months & $P$ & $\begin{array}{l}\text { Basal } \\
46 \text { pts }\end{array}$ & At 6 months & $P$ & $\begin{array}{l}\text { Basal } \\
42 \mathrm{pts}\end{array}$ & At 12 months & $P$ \\
\hline S. Creat. mg/dL & $\begin{array}{c}0.76 \\
0.68-1.6\end{array}$ & $\begin{array}{c}0.76 \\
0.65-0.89\end{array}$ & Ns & $\begin{array}{l}0.87 \\
0.7-1\end{array}$ & $\begin{array}{l}0.85 \\
0.7-1\end{array}$ & Ns & $\begin{array}{c}0.82 \\
0.67-0.96\end{array}$ & $\begin{array}{c}0.74 \\
0.67-0.93\end{array}$ & Ns \\
\hline Proteinuria g/day & $\begin{array}{c}2.5 \\
1.8-4 \\
\end{array}$ & $\begin{array}{c}0.94 \\
0.52-4.2 \\
\end{array}$ & Ns & $\begin{array}{c}2.2 \\
1.3-3.9 \\
\end{array}$ & $\begin{array}{c}0.92 \\
0.3-1.5 \\
\end{array}$ & 0.0000 & $\begin{array}{c}3.0 \\
2.05-4.9 \\
\end{array}$ & $\begin{array}{c}0.51 \\
0.23-1.26 \\
\end{array}$ & 0.0000 \\
\hline ESR mm & $\begin{array}{c}65 \\
25.7-82 \\
\end{array}$ & $\begin{array}{c}36.5 \\
10.5-51.7 \\
\end{array}$ & 0.04 & $\begin{array}{c}29.5 \\
12-63.7 \\
\end{array}$ & $\begin{array}{c}21.5 \\
14.2-31.2 \\
\end{array}$ & Ns & $\begin{array}{c}33 \\
20-67 \\
\end{array}$ & $\begin{array}{c}13.5 \\
10.2-32.7 \\
\end{array}$ & 0.0003 \\
\hline CRP mg/dL & $\begin{array}{c}0.47 \\
0.261 .1 \\
\end{array}$ & $\begin{array}{c}0.30 \\
0.2-1.32 \\
\end{array}$ & Ns & $\begin{array}{c}0.29 \\
0.09-0.7 \\
\end{array}$ & $\begin{array}{c}0.1 \\
0.06-0.28 \\
\end{array}$ & 0.005 & $\begin{array}{c}0.31 \\
0.12-0.61 \\
\end{array}$ & $\begin{array}{c}0.1 \\
0.04-0.2 \\
\end{array}$ & 0.005 \\
\hline $\mathrm{C} 3 \mathrm{mg} / \mathrm{dL}$ & $\begin{array}{c}67 \\
60-87 \\
\end{array}$ & $\begin{array}{c}83 \\
74.5-100.5 \\
\end{array}$ & 0.03 & $\begin{array}{c}73 \\
47.2-87.7 \\
\end{array}$ & $\begin{array}{c}92 \\
79-108 \\
\end{array}$ & 0.0000 & $\begin{array}{c}63 \\
48-81.2 \\
\end{array}$ & $\begin{array}{c}86.5 \\
71-101.5\end{array}$ & 0.0000 \\
\hline $\mathrm{C} 4 \mathrm{mg} / \mathrm{dL}$ & $\begin{array}{c}10 \\
8-13\end{array}$ & $\begin{array}{c}13 \\
9-20\end{array}$ & Ns & $\begin{array}{c}10 \\
5.2-16.7\end{array}$ & $\begin{array}{c}17 \\
11-21\end{array}$ & 0.0000 & $\begin{array}{c}9 \\
5-14.7 \\
\end{array}$ & $\begin{array}{c}13.5 \\
10-20\end{array}$ & 0.001 \\
\hline $\begin{array}{l}\text { Anti-DNA Ab } \\
\text { UmL }\end{array}$ & $\begin{array}{c}79.5 \\
10.0-291\end{array}$ & $\begin{array}{c}38 \\
11.7-85 \\
\end{array}$ & 0.01 & $\begin{array}{c}173 \\
69.5 .400 \\
\end{array}$ & $\begin{array}{c}71.7 \\
15.7-84.7 \\
\end{array}$ & 0.0000 & $\begin{array}{c}124 \\
83.7-345 \\
\end{array}$ & $\begin{array}{c}48 \\
34-104 \\
\end{array}$ & 0.0000 \\
\hline Anti-Clq Ab AU & $\begin{array}{c}120.5 \\
52-315\end{array}$ & $\begin{array}{c}52.5 \\
39-121 \\
\end{array}$ & 0.002 & $\begin{array}{c}94 \\
35-234 \\
\end{array}$ & $\begin{array}{c}50 \\
22.7-108.5 \\
\end{array}$ & 0.0003 & $\begin{array}{c}147 \\
56-320\end{array}$ & $\begin{array}{c}65 \\
35.7-122 \\
\end{array}$ & 0.0000 \\
\hline $\begin{array}{l}\text { Anti-nucleosome } \\
\mathrm{Ab}\end{array}$ & $\begin{array}{c}66 \\
42.7-110 \\
\end{array}$ & $\begin{array}{c}58 \\
39-83 \\
\end{array}$ & 0.04 & $\begin{array}{c}97.5 \\
30-118 \\
\end{array}$ & $\begin{array}{c}41 \\
13-56 \\
\end{array}$ & 0.0001 & $\begin{array}{c}88 \\
51-109 \\
\end{array}$ & $\begin{array}{c}32 \\
16-70 \\
\end{array}$ & 0.0001 \\
\hline Anti-ribosome Ab & $\begin{array}{c}2.5 \\
1.75-4\end{array}$ & $\begin{array}{c}2 \\
2-3\end{array}$ & Ns & $\begin{array}{l}3.5 \\
2-6 \\
\end{array}$ & $\begin{array}{c}2 \\
2-3.5 \\
\end{array}$ & 0.0007 & $\begin{array}{c}2 \\
2-10 \\
\end{array}$ & $\begin{array}{c}2 \\
2-3 \\
\end{array}$ & Ns \\
\hline
\end{tabular}

The data are reported as Median and interquartile ranges: $\mathrm{S} .=$ serum, Creat. $=$ creatinine, $\mathrm{ESR}=$ erythrocyte sedimentation rate, $\mathrm{CPR}=\mathrm{C}$ reactive protein, and $\mathrm{Ab}=$ antibodies.

TABle 5: Predictors of complete renal remissions among the clinical and the immunological tests at renal biopsy.

\begin{tabular}{|c|c|c|c|}
\hline & $\begin{array}{c}\text { Complete remission } \\
39 \text { patients }\end{array}$ & $\begin{array}{c}\text { No complete remission } \\
65 \text { patients }\end{array}$ & $P$ \\
\hline Months of therapy & $6.0(5.2-7.4)$ & $5.2(3.5-6.8)$ & 0.02 \\
\hline Serum creatinine $\mathrm{mg} / \mathrm{dL}$ & $0.83(0.64-0.95)$ & $0.85(0.7-1.26)$ & 0.15 \\
\hline Proteinuria g/day & $1.96(12-2.76)$ & $3.45(2.1-5)$ & 0.0009 \\
\hline Hemoglobin g/dL & $12.0(11.0-12.9)$ & $11.6(10-12.7)$ & 0.12 \\
\hline Erythrocyte sedimentation rate & $33(17.5-61.2)$ & $39(16-73)$ & 0.7 \\
\hline $\mathrm{C}$ reactive protein $\mathrm{mg} / \mathrm{dL}$ & $0.3(0.09-1.22)$ & $0.3(0.14-0.67)$ & 0.6 \\
\hline $\mathrm{C} 3 \mathrm{mg} / \mathrm{dL}$ & $66(48-82.2)$ & $70(48-88)$ & 0.5 \\
\hline $\mathrm{C} 4 \mathrm{mg} / \mathrm{dL}$ & $9(5.2-115.7)$ & $10(5-14)$ & 0.7 \\
\hline Anti DNA antibodies $\mathrm{U} / \mathrm{mL}$ & $147(83.5-380)$ & $132(43-400)$ & 0.5 \\
\hline Anti Clq antibodies AU & $120(35-320)$ & $128(42.5-320)$ & 0.5 \\
\hline Anti-nucleosome antibodies $U$ & $88(57-111)$ & $92.5(33.2-115.7)$ & 0.8 \\
\hline Anti-DNA $>55 \mathrm{U} / \mathrm{mL}$ or anti-Clq $>50 \mathrm{AU}$ antibodies & $34(87 \%)$ & $58(89,2 \%)$ & 1 \\
\hline Anti-ribosome antibodies & $2(2-5.5)$ & $2(2-5.7)$ & 0.1 \\
\hline
\end{tabular}

The data are reported as Median and interquartile ranges.

only test correlated with the clinical presentation of LN. After the beginning of therapy, the titer of the autoantibodies progressively and significantly reduced, but none of them was predictive of complete renal remission. The results of this work, which outlines the role of autoantibodies and in particular of anti-Clq, in defining the activity of lupus nephritis at the time of renal biopsy, confirm their utility in diagnosing the acute exacerbations of LN made on clinical grounds only.

\section{Conflict of Interests}

The authors declare that there is no conflict of interests regarding the publication of this paper.

\section{Acknowledgments}

The work was supported by the Grant "Project in glomerulonephritis" in memory of Pippo Neglia. The authors would 
like to thank Marina Balderacchi and Andrea Centa for their secretarial assistance.

\section{References}

[1] R. Cervera, M. A. Khamashta, J. Font et al., "Morbidity and mortality in systemic lupus erythematosus during a 10 -year period: a comparison of early and late manifestations in a cohort of 1,000 patients," Medicine, vol. 82, no. 5, pp. 299-308, 2003.

[2] G. Moroni, S. Quaglini, M. Maccario, G. Banfi, and C. Ponticelli, "Nephritic flares' are predictors of bad long-term renal outcome in lupus nephritis," Kidney International, vol. 50, no. 6, pp. 2047-2053, 1996.

[3] C. T. Ravirajan, L. Rowse, J. R. MacGowan, and D. A. Isenberg, "An analysis of clinical disease activity and nephritis-associated serum autoantibody profiles in patients with systematic lupus erythematosus: a cross-sectional study," Rheumatology, vol. 40, no. 12, pp. 1405-1412, 2001.

[4] A. Ho, L. S. Magder, S. G. Barr, and M. Petri, "Decreases in antidouble-stranded DNA levels are associated with concurrent flares in patients with systemic lupus erythematosus," Arthritis \& Rheumatism, vol. 44, no. 10, pp. 2342-2349, 2001.

[5] M. D. Linnik, J. Z. Hu, K. R. Heilbrunn et al., "Relationship between anti-double-stranded DNA antibodies and exacerbation of renal disease in patients with systemic lupus erythematosus," Arthritis \& Rheumatism, vol. 52, no. 4, pp. 1129-1137, 2005.

[6] J. M. Esdaile, M. Abrahamowicz, L. Joseph, T. MacKenzie, Y. $\mathrm{Li}$, and D. Danoff, "Laboratory tests as predictors of disease exacerbations in systemic lupus erythematosus: why some tests fail," Arthritis and Rheumatism, vol. 39, no. 3, pp. 370-378, 1996.

[7] C. Bigler, M. Lopez-Trascasa, E. Potlukova et al., "Antinucleosome antibodies as a marker of active proliferative lupus nephritis," The American Journal of Kidney Diseases, vol. 51, no. 4, pp. 624-629, 2008.

[8] N. Bizzaro, D. Villalta, D. Giavarina, and R. Tozzoli, "Are anti-nucleosome antibodies a better diagnostic marker than anti-dsDNA antibodies for systemic lupus erythematosus? A systematic review and a study of metanalysis," Autoimmunity Reviews, vol. 12, no. 2, pp. 97-106, 2012.

[9] C. E. H. Siegert, M. R. Daha, C. M. E. S. Tseng, I. E. M. Coremans, L. A. van Es, and F. C. Breedveld, "Predictive value of IgG autoantibodies against $\mathrm{Clq}$ for nephritis in systemic lupus erythematosus," Annals of the Rheumatic Diseases, vol. 52, no. 12, pp. 851-856, 1993.

[10] M. Trendelenburg, J. Marfurt, I. Gerber, A. Tyndall, and J. A. Schifferli, "Lack of occurrence of severe lupus nephritis among anti-Clq autoantibody-negative patients," Arthritis \& Rheumatism, vol. 42, no. 1, pp. 187-188, 1999.

[11] R. A. Sinico, A. Radice, M. Ikehata et al., "Anti-Clq autoantibodies in lupus nephritis: prevalence and clinical significance," Annals of the New York Academy of Sciences, vol. 1050, pp. 193200, 2005.

[12] N. Marto, M. L. Bertolaccini, E. Calabuig, G. R. V. Hughes, and M. A. Khamashta, "Anti-Clq antibodies in nephritis: correlation between titres and renal disease activity and positive predictive value in systemic lupus erythematosus," Annals of the Rheumatic Diseases, vol. 64, no. 3, pp. 444-448, 2005.

[13] I. E. M. Coremans, P. E. Spronk, H. Bootsma et al., "Changes in antibodies to Clq predict renal relapses in systemic lupus erythematosus," American Journal of Kidney Diseases, vol. 26, no. 4, pp. 595-601, 1995.
[14] G. Moroni, M. Trendelenburg, N. Del Papa et al., "AntiClq antibodies may help in diagnosing a renal flare in lupus nephritis," The American Journal of Kidney Diseases, vol. 37, no. 3, pp. 490-498, 2001.

[15] E. Akhter, R. W. Burlingame, A. L. Seaman, L. Magder, and M. Petri, "Anti-Clq antibodies have higher correlation with flares of lupus nephritis than other serum markers," Lupus, vol. 20, no. 12, pp. 1267-1274, 2011.

[16] G. Moroni, A. Radice, G. Giammarresi et al., "Are laboratory tests useful for monitoring the activity of lupus nephritis? A 6year prospective study in a cohort of 228 patients with lupus nephritis," Annals of the Rheumatic Diseases, vol. 68, no. 2, pp. 234-237, 2009.

[17] M. C. Hochberg, "Updating the American College of Rheumatology revised criteria for the classification of systemic lupus erythematosus," Arthritis and rheumatism, vol. 40, no. 9, p. 1725, 1997.

[18] J. J. Weening, V. D. D'Agati, M. M. Schwartz et al., "The classification of glomerulonephritis in systemic lupus erythematosus revisited," Journal of the American Society of Nephrology, vol. 15, no. 2, pp. 241-250, 2004.

[19] H. A. Austin III, D. T. Boumpas, E. M. Vaughan, and J. E. Balow, "Predicting renal outcomes in severe lupus nephritis: contributions of clinical and histologic data," Kidney International, vol. 45, no. 2, pp. 544-550, 1994.

[20] L. Andreoli, F. Pregnolato, R. W. Burlingame et al., "Antinucleosome antibodies in primary antiphospholipid syndrome: a hint at systemic autoimmunity?" Journal of Autoimmunity, vol. 30, no. 1-2, pp. 51-57, 2008.

[21] C. C. Mok, L. Y. Ho, H. W. Leung, and L. G. Wong, "Performance of anti-Clq, antinucleosome, and anti-dsDNA antibodies for detecting concurrent disease activity of systemic lupus erythematosus," Translational Research, vol. 156, no. 6, pp. 320-325, 2010.

[22] M. Mosca, D. Chimenti, F. Pratesi et al., "Prevalence and clinicoserological correlations of anti- $\alpha$-enolase, anti-Clq, and antidsDNA antibodies in patients with systemic lupus erythematosus," The Journal of Rheumatology, vol. 33, no. 4, pp. 695-697, 2006.

[23] H. Julkunen, S. Ekblom-Kullberg, and A. Miettinen, "Nonrenal and renal activity of systemic lupus erythematosus: a comparison of two anti-Clq and five anti-dsDNA assays and complement C3 and C4," Rheumatology International, vol. 32, no. 8, pp. 2445-2451, 2012.

[24] M. Trendelenburg, M. Lopez-Trascasa, E. Potlukova et al., "High prevalence of anti-Clq antibodies in biopsy-proven active lupus nephritis," Nephrology Dialysis Transplantation, vol. 21, no. 11, pp. 3115-3121, 2006.

[25] X.-W. Yang, Y. Tan, F. Yu, and M.-H. Zhao, "Combination of anti-Clq and anti-dsDNA antibodies is associated with higher renal disease activity and predicts renal prognosis of patients with lupus nephritis," Nephrology Dialysis Transplantation, vol. 27, no. 9, pp. 3552-3559, 2012.

[26] Q.-Y. Fang, F. Yu, Y. Tan et al., "Anti-Clq antibodies and IgG subclass distribution in sera from Chinese patients with lupus nephritis," Nephrology Dialysis Transplantation, vol. 24, no. 1, pp. $172-178,2009$.

[27] C. Grootscholten, J. W. C. Dieker, F. D. McGrath et al., "A prospective study of anti-chromatin and anti-Clq autoantibodies in patients with proliferative lupus nephritis treated with 
cyclophosphamide pulses or azathioprine/methylprednisolone," Annals of the Rheumatic Diseases, vol. 66, no. 5, pp. 693696, 2007.

[28] A. Matrat, C. Veysseyre-Balter, P. Trolliet et al., "Simultaneous detection of anti-Clq and anti-double stranded DNA autoantibodies in lupus nephritis: predictive value for renal flares," Lupus, vol. 20, no. 1, pp. 28-34, 2011.

[29] P. Oelzner, B. Deliyska, R. Fünfstück, G. Hein, D. Herrmann, and G. Stein, "Anti-Clq antibodies and antiendothelial cells antibodies in systemic lupus erythematosus-relationship with disease activity and renal involvement," Clinical Rheumatology, vol. 22, no. 4-5, pp. 271-278, 2003.

[30] A. Kumar, R. Gupta, T. Varghese, R. M. Pande, V. K. Singal, and O. P. Garg, "Anti-Clq antibody as a marker of disease activity in systemic lupus erythematosus," Indian Journal of Medical Research, vol. 110, pp. 190-193, 1999.

[31] O. C. Meyer, P. Nicaise-Roland, N. Cadoudal et al., "Anti$\mathrm{Clq}$ antibodies antedate patent active glomerulonephritis in patients with systemic lupus erythematosus," Arthritis Research \& Therapy, vol. 11, no. 3, article R87, 2009.

[32] M. A. Seelen, L. A. Trouw, and M. R. Daha, "Diagnostic and prognostic significance of anti-Clq antibodies in systemic lupus erythematosus," Current Opinion in Nephrology and Hypertension, vol. 12, no. 6, pp. 619-624, 2003.

[33] M. Mahler, R. A. van Schaarenburg, and L. A. Trouw, "AntiClq autoantibodies, novel tests, and clinical consequences," Frontiers in Immunology, vol. 4, article 117, 2013. 


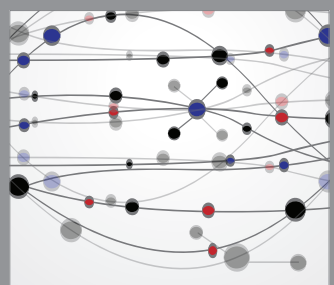

The Scientific World Journal
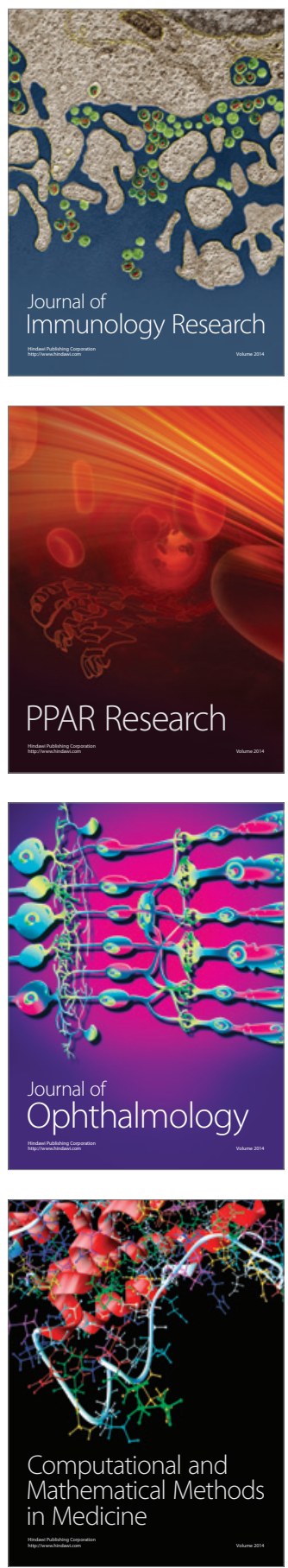

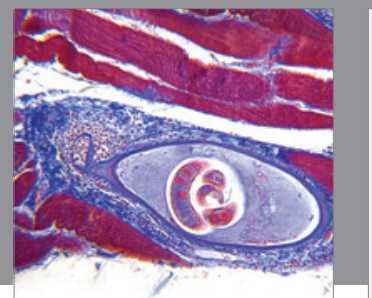

Gastroenterology

Research and Practice
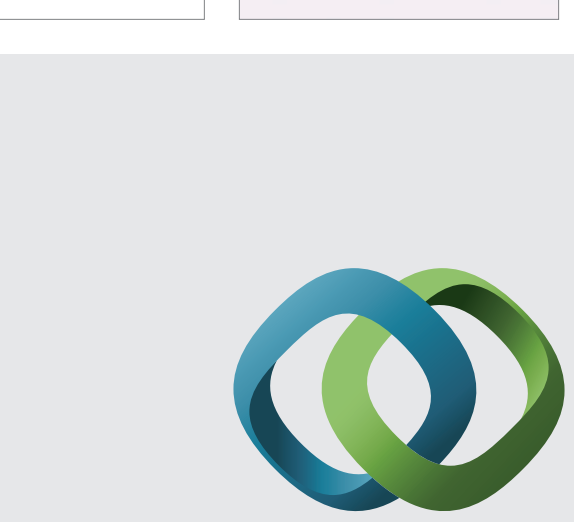

\section{Hindawi}

Submit your manuscripts at

http://www.hindawi.com
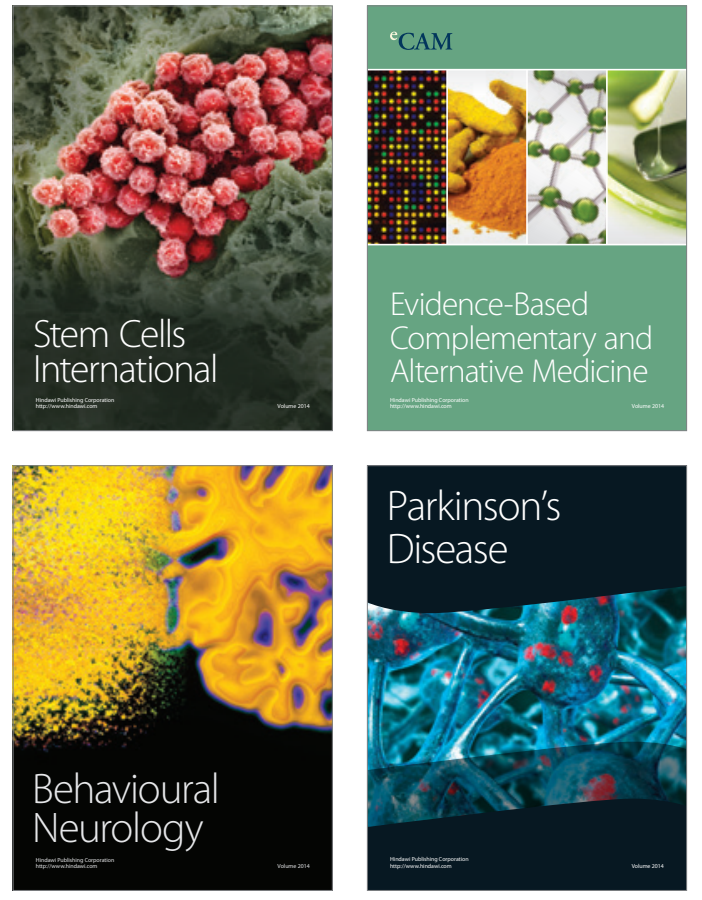
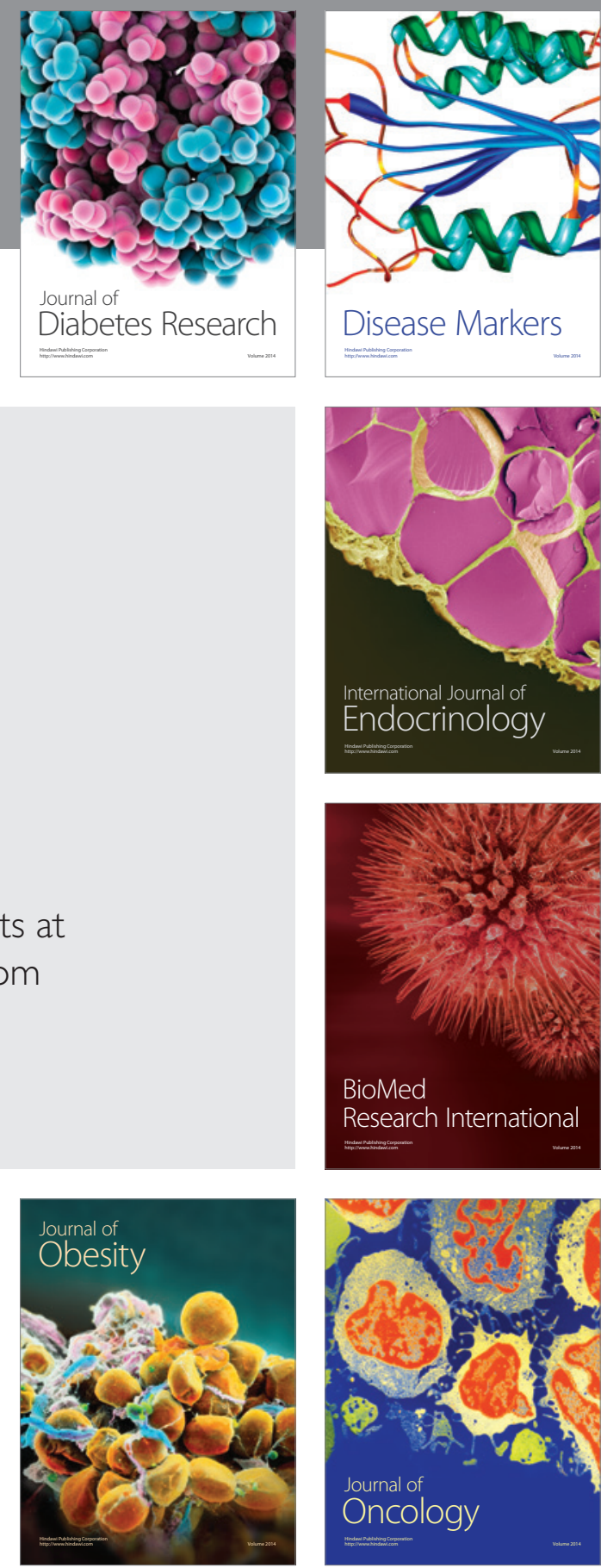

Disease Markers
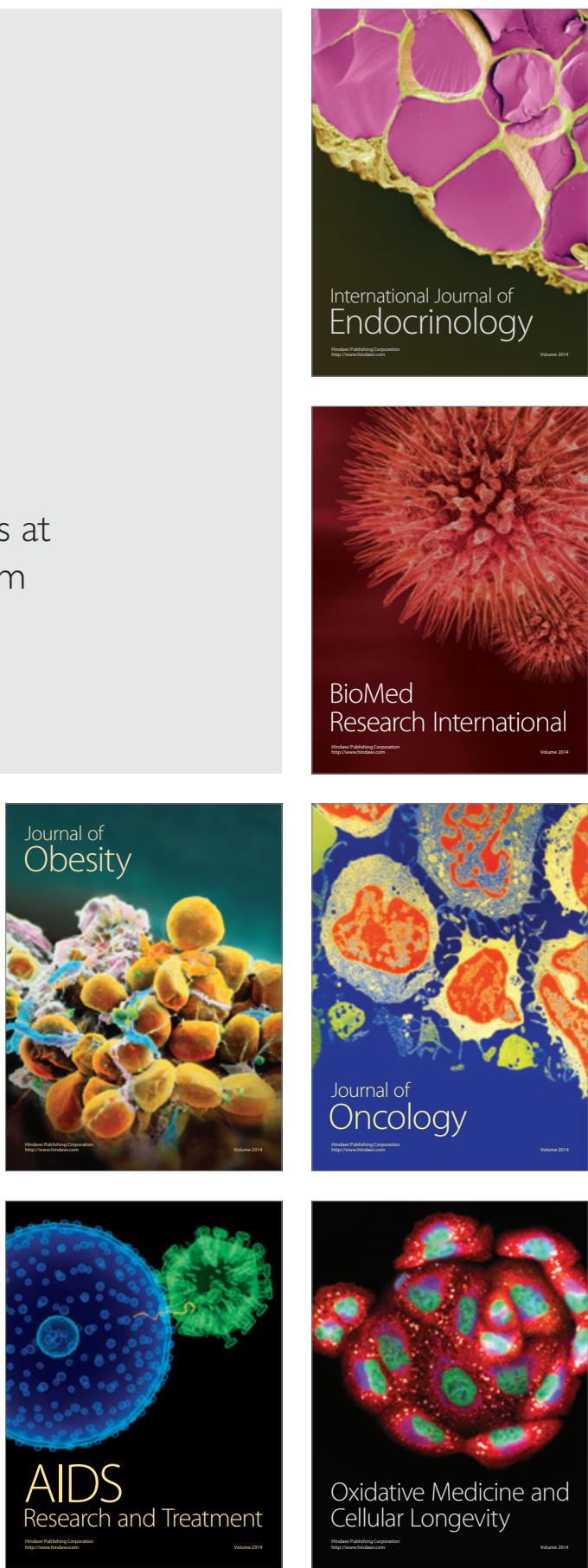